\section{TERCENTENARY OF DENIS PAPIN}

\author{
By DR. H. W. DICKINSON
}

T HE tercentenary of the birth of one of France's famous sons, the natural philosopher, Denis Papin, occurs this year and is being marked by commemorative meetings there; and there is every reason for taking cognizance of the event in Britain, for it was here that he carried out much of his scientific work.

The time in which Papin was born was propitious, for it was marked by the quickening of the world of ideas after the comparative stagnation of the Middle Ages and by the rise of a new system of philosophy resting on a basis of experiment and observation, of which Francis Bacon, Viscount St. Albans, was the earliest and most distinguished exponent in Britain. This new attitude to knowledge led to the foundation of scientific societies in many cities of Europe, of which we need only mention the Royal Society, London, 1662, and the Académie Royale des Sciences, Paris, 1666.

Renewed interest in Papin and his work has been aroused by the formation of a Comité Denis Papin to commemorate the tercentenary, and this has led, in one direction, to inquiry as to his birth, hitherto believed to have taken place at Blois in the Duchy of Orléans (now Département Loir-et-Cher). Recently, by the researches of M. J. Chavigny of Blois, it has been shown that Papin was born at the farmhouse of the Papin family at Coudraies, $1 \frac{1}{2}$ miles from Chitenay, which itself is twelve miles from Blois. It was at Blois that Papin was christened on August 22, 1647; this has led to the statement, hitherto quite naturally accepted, about his birth. It was as an outcome of this discovery that the Denis Papin Committee, with the co-operation of the Maire and Commune of Chitenay, organised a celebration in the village on July 20 , in the course of which a tablet on the farmhouse was unveiled by Prof. A. Portevin, representing the French Academy, in the presence of delegates from foreign countries and an assembly of the local inhabitants. The inscription on the tablet is as follows:

\section{Closerie des Papins \\ Dans cette maison serait ne \\ Denis Papin en Aôt 1647. \\ Offert par le $\overrightarrow{-}-\vec{m}$ 20 juillet 1947}

The uncommon word 'closerie' has no exact equivalent in English-it connoted originally a peasant holding of land worked on the metayer system ; perhaps we may translate it 'farmsteading'.

Papin early displayed ability, and by the help and encouragement possibly of his uncle and grandfather, who were physicians, he was enabled to proceed to the University of Angers, at the capital of Anjou, to study there, and in 1669 he took the degree of M.D. He practised in the city for some years as a physician, but like so many provincials he was attracted to Paris. There he became assistant to the celebrated Christiaan Huygens, who had been invited to Paris in 1666 by the great finance minister, Colbert, to establish the Académie des Sciences on a secure foundation.

In Paris, Papin was employed on experimental physics, notably on the air pump. This research enabled him in 1674 to publish his "Nouvelles Expériences du Vuide". Alarmed probably by the growing danger that threatened those of the Protest. ant faith-for Papin was a Huguenot-he emigrated to England in 1675, anticipating by ten years the revocation of the Edict of Nantes. He found employment as assistant to the Hon. Robert Boyle. At that time the latter was busy on improvements in the air pump, and Papin's experience was just what was wanted. Incidentally, he helped at the meetings of the Royal Society. One of the most notable of those he met in this way was Robert Hooke, curator of experiments to the Society since 1662. The duty of the curator was to produce and demonstrate experiments in physics, chemistry and mechanics at the weekly meetings. This tended, of course, for his energies to be dissipated over too wide a field, and it was probably a relief to him when Papin in 1679 was appointed his successor, but at the reduced salary of $£ 20$ a year. It involved a busy time, and the collaboration with the pregnant mind of Hooke could not have been otherwise than stimulating. While thus engaged, in 1681 Papin invented his "New Digester or Engine for Softening Bones", in which animal products are stewed by heat under pressure; this was a great advance in technique fraught with many valuable applications in subsequent years. To limit the pressure in the digester and so avoid bursting it, Papin employed the lever safety valve, with the invention of which he is not quite correctly credited; what is certain is that he was the first to illustrate it in print, and this was in the thesis that he wrote in 1681 with the above title; a version in French, "La manière d'amollir les os", also appeared in the following year. John Evelyn, in his "Diary" under date April 5, 1682, tells with gusto and appreciation of a supper cooked with the digester and partaken of in company with other fellows of the Royal Society after a meeting. $\mathrm{He}$ remarks: "This philosophical supper caus'd much mirth amongst us and exceedingly pleas'd all the company", as one can well imagine.

In 1680 Papin was elected a fellow of the Royal Society, but strangely enough his signature does not appear on the roll of fellows, possibly because just prior to the election, as Evelyn states: "he has since gone to Venice with the late President here [Sarotti] ... who carried this excellent mechanic, philosopher and physician to set up a philosophical meeting in that eity". He did actually take this journey and accept the employment in 1681 ; but the institution thus set up lasted a few years only and he was back again in London in 1684, where he was re-appointed curator of experiments to the Royal Society. However, in 1685 he was appointed by the Landgrave Carl of Hessen Nassau professor of mathematics in the University of Marburg. It was here in 1690 that he published an account of experiments with an apparatus that has been acclaimed as the genesis of the steam engine. A film of water, contained in the bottom of a cylinder fitted with a piston, was placed over a fire, when the water was turned into steam and lifted the piston, which was then latched in the raised position. The apparatus was then moved from the fire and allowed to cool. On unlatching the piston, it was pushed down by the atmospheric pressure above it and raised a weight by a cord over a pulley. $\mathrm{He}$ does not say how long the experiment took. Obviously this was nothing more than a lecture-table experiment, and went no distance in the direction of making a working engine of it. As time went on, Papin gradually changed his conceptions and inclined towards using steam under considerable pressure, for 
in 1698 , replying to a query by the celebrated philosopher G. W. F. Leibniz at Hanover, with whom Papin had been since 1692 in close correspondence, he says: "The manner in which at present I employ fire for raising water is always on the principle of the rarefaction of water. Only I do so at present in a manner much more easy of execution than that which I have published; furthermore as well as using suction, I employ also the pressure that water exerts on other bodies in expending (by heat) the effects of which are not limited like those of suction. Thus I am persuaded that this invention if it can be pushed as it should be could prove of very considerable utility, but I have not yet made great progress."

The outcome of this was that, in 1707, Papin set down his conclusions in a work published at Cassel entitled "Nouvelle Manière pour lever l'eau par la force de feu". In this he advocated an apparatus similar to, though perhaps not so efficient as, the 'fire engine' patented and introduced in 1698 by that prolific inventor Thomas Savery, in which steam at high pressure was used to raise water much in the way that is done by the pulsometer of to-day. Evidence that Papin's engine was made and used is lacking, but had it been so there is no reason to believe that it would have been any more successful than that of Savery; the latter, unlike Papin, was a practical man, with a workshop in Salisbury Court, Fleet Street, London, and if anyone could have made the fire engine a success he could. The fact was that both the philosophers and the practical men of the day were thinking along the wrong lines, for in the then state of the mechanic arts steam boilers could not be made to stand the high pressure that they required. It was reserved for Thomas Newcomen, an ironmonger of Dartmouth, Devon, who, recognizing the limitations of craftsmanship and of the materials at his hand, employed steam of no higher pressure than that of the atmosphere under a piston in a cylinder and condensed the steam with a jet of water, thereby succeeding by 1712 in inventing a practical engine. Papin can be awarded the credit that he was the first to suggest that by creating a vacuum under a piston in a cylinder the pressure of the atmosphere could be made to do work.

The truth is that Papin was a most fertile inventor - his brain teemed with ideas-but time and opportunity did not allow, or was not allowed, to serve to reduce them to practical working machines. We may instance the Hessian pump, which was the undoubted forerunner of the centrifugal pump of a century and a half later. Papin took up many other schemes that it would be tedious to enumerate, and we shall only mention his mechanically propelled boat, by which, having decided in 1707 to return to England, he had the crazy idea for a man in his sixtieth year of paddling down the River Weser to Bremen. Starting from Cassel along the River Fulda, he got as far as Münden, the junction with the Weser, when he was stopped not only by the customs authorities but also by the bargemen, who feared that their livelihood was threatened by the new-fangled craft. The statement that he employed his steam engine to propel the boat is more than doubtful. Undeterred, he continued his journey overland, and on arrival in England, he seems to have received a cool reception. Several of his good friends had died while he had been away : Boyle in 1691; Sir Joseph Williamson, who had been president $(1677-80)$ of the Royal Society; and Hooke in 1703; Richard
Waller, appointed in 1682 to succeed Hooke, was now secretary to the Society.

On February 11, 1708, Papin submitted to the Royal Society a proposition to "construct a boat to be rowed by oars moved with heat", following on the lines of the one he had built at Cassel; but the Society would not advance the requisite sum, estim. ated at 115 , for the experiment, and so the project fell through. How he lived during the next four years we can only surmise. In 1711 alone he submitted six papers to the Royal Society. In the last letter extant from him, addressed to Sir Hans Sloane and dated January 23, 1712, he concludes pathetically but bravely, "Certainly, Sir, I am in a sad case since even by doing good I draw ennemi's upon me, yet for all that I fear nothing because I rely on God Allmighty'. We hear nothing further about him, and the supposition is that he died a few months later in Soho, where he had been living. All efforts to find out particulars of his death have been unsuccessful. Thus passed away an acute natural philosopher, a clever mechanician and a fertile inventor, who sowed the seeds of several inventions that were to bear fruit in after years.

Further steps to commemorate the tercentenary are being taken. An exhibition of documents, models and drawings concerning him and his work was held at Blois during August; to this the Royal Society contributed microfilms of all Papin documents still in its possession. His baptism was commemorated on August 22 in the church at Blois ; and a ceremony will take place at Angers to recall the conferring of his doctorate of medicine. In October an exhibition will be held at the Conservatoire des Arts et Métiers, Paris, including much of the material shown at Blois; finally, a commemorative meeting at the Sorbonne is being arranged.

\section{PLANT BREEDERS' CONFERENCE AT CAMBRIDGE}

A COMPREHENSIVE picture of all the phases of plant breeding work at Cambridge was seen by plant breeders assembled for the first conference called by the Agricultural Research Council and held during July 9-11, for workers from the Aberystwyth, Cambridge and Corstorphine Plant Breeding Stations and the John Innes Horticultural Institution, Merton. Such conferences were recommended by the Plant Breeding Survey Group of the Agricultural Research Council and in future years will meet at the other stations in turn, enabling workers at breeding stations supported by the Council in Great Britain to learn the main outlines of the work at the other institutions and to discuss their common problems.

The conference was rather informal; talks and laboratory and field demonstrations were used to describe to the visitors the work of the Cambridge University Plant Breeding Institute, and visits were also paid to the Imperial Agricultural Bureaux Empire Potato Collection, the Horticultural Research Station and the National Institute of Agricultural Botany.

The Plant Breeding Institute, one of the research institutes of the School of Agriculture, is engaged in the improvement. of wheat, barley, oats, potatoes, sugar beet and forage crops. The staff of the Institute at present consists of Dr. G. D. H. Bell (acting director), Sir Frank Engledow, Mr. C. 